\title{
THE DEATH OF THE BUSINESS PLAN: MORE THAN EVER, LEARNING PLANS AND NOT BUSINESS PLANS ARE MEANT TO ANALYZE MOST OF BUSINESS GROWTH ALTERNATIVES
}

\author{
Leandro A. Viltard \\ Universidad de Buenos Aires \\ Professor at Universidad Católica Argentina \\ Universidad de Palermo, Argentina \\ E-mail: Iviltard@yahoo.com.ar
}

Submission: $13 / 08 / 2015$

Revision: $28 / 08 / 2015$

Accept: 28/08/2015

\section{ABSTRACT}

This article explores the nature and scope of Business Plans (BP) and Learning Plans (LP), and its objective is to verify the circumstances in which these tools become applicable.

It states that competitiveness and productivity must be understood through the globalization borderless geography, the identification of innovation key drivers, the achievement of a sustainable competitive advantage, the distinction between functional and innovative products and finally the application of the right management/business tools. In this context, LPs portray a flexible work plan and a learning process for fast-changing times. The final conclusion, is that as the unpredictability is part of our common lives today and business as usual should be rare, BPs are about to die.

This is a qualitative investigation and the research design is transversal and not experimental.

To verify the circumstances in which Business Plans (BP) and Learning Plans (LP) become applicable.

Keywords: Business Plan; Learning Plan; Globalization; Innovation; Functional product; Innovative product. 
INDEPENDENT JOURNAL OF MANAGEMENT \& PRODUCTION (IJM\&P)

http://www.ijmp.jor.br

v. 6, n. 4, October - December 2015

ISSN: 2236-269X

DOI: 10.14807/ijmp.v6i4.361

\section{INTRODUCTION}

Determining what customers want and the right markets to launch products represents a fundamental consideration for business people. That is why markets and products have a difficult interrelationship for many firms' executives as unknown and unpredicted factors usually abound in our volatile and fast world.

In this perspective, globalization is one of the key drivers for business growth and it generally implies the deployment of different activities across the value chain in diverse geographies. These activities include strategic/ market analysis, forecasting and planning, inventory management, resources management, efficient production, work scheduling and fast time-to-market. To "do the right things, right" is a matter of good business perspective and future sustainability.

In other words, competitiveness and productivity is a matter of a thorough comprehension of the following subjects that are covered in the present study:

- Globalization: As a process, that changes the rules of the overall game with enormous implications on society and firm's activities.

- Innovation key drivers: to identify and apply them to the day-to-day operation.

- Competitive advantage: to apart the firm from competitors.

- Functional and innovative products: to set up the right organization, processes and practices.

- Management/business tools: to evaluate investments in markets and products. This investments should sustain future business decisions and be supported by appropriate analysis and metrics.

The final step in being competitive and productive is to establish proper qualitative, quantitative and timing demand objectives to be able to respond to customers' needs. In this sense and as of now, Business Plans (BP) seemed to be the right tool to respond to these fundamental factors but there are some considerations that will come up in this paper which will show additional perspectives on the matter. 
DOI: 10.14807/ijmp.v6i4.361

\subsection{Objective of this investigation}

To verify the circumstances in which Business Plans (BP) and Learning Plans (LP) become applicable.

\subsection{2 Design: Methodology and analysis}

The study was exploratory and descriptive, and a qualitative methodology was used. Its design was not experimental and transversal, as the information was collected at a given moment in time.

The unit of analysis was related to business organizations. We tried to ensure that prior knowledge did not hinder the analysis that was done.

The research is based on the work of significant and well known specialists on the field and our own experience on the matter.

This investigation was conducted in Argentina between Jan. 2015 - Aug. 2015.

\subsection{Research Limitations/Clarifications}

Although we recognize that it is very difficult to ascertain that all relevant information has been included, we referred to worldwide information from relevant secondary sources. As a result, an empirical study was not used.

Not to undermine the content and the investigation's purpose, the conclusions and opinions that were expressed are strictly based on the information obtained from the analyzed data.

As a qualitative investigation, the results that are shown cannot be generalized, although they are useful for decision-making purposes. Our objective is to enhance the knowledge on the matter and improve the startup processes through new tools and novel perspectives.

\subsection{Findings}

There are certain conditions in which Business Plans (BP) could be applied but, more than ever and because of globalization borderless geography, innovation and competitive advantages uncertainties, and the distinction that should be made between functional and innovative products, firms should focus on Learning Plans (LP) not on Business Plans (BP). Surely, there are cultural biases that come from old 
INDEPENDENT JOURNAL OF MANAGEMENT \& PRODUCTION (IJM\&P)

http://www.ijmp.jor.br

v. 6, n. 4, October - December 2015

ISSN: 2236-269X

DOI: 10.14807/ijmp.v6i4.361

paradigms that are still being pursued, and a lot of questions that haven't been asked by managers yet. That is why this paper highlights fundamental differences between BP and LP.

\subsection{Originality and Value}

This research has been an attempt to explore BP and LP as tools to monitor business/product development. Actual consideration of managers and executives of value perception when using BP for functional and innovative products and for every market could distort the intended objectives, impeding the appropriate implementation of new businesses.

As a result, LPs are shown as a contribution to launching novel businesses/products and expanding the organizational learning processes to achieve the proposed success.

In addition, there had not been made many studies on this matter. That is why the study of this phenomenon could help firms progress on new businesses/products implementation results.

\section{UNDERSTANDING GLOBALIZATION}

In prior work1, it was stated that new powers are setting up an unknown framework, configuring complex scenes in which boundaries and spaces that are yet to be deciphered. Its final goal is to help decision factors (meaning: officials, entrepreneurs, executives and individuals) to find better answers to globalization, which has changed the physiognomy of much of the known.

In the following paragraphs, some of the basic considerations on the four aspects analyzed in the book in order to understand this particular, complex, multidimensional and controversial phenomenon and its implications on firms' decisions are being presented.

\subsection{Culture and society}

It is the end of closed universes, and global cities with new users/customers are flourishing in today's world.

1 Viltard, L. A. (2013) Globalización: Entender el nuevo ámbito mundial y tomar decisiones (Globalization: Understanding the new worldwide context and take decisions), B.S. Lab, Italia: Avellino. 
INDEPENDENT JOURNAL OF MANAGEMENT \& PRODUCTION (IJM\&P)

http://www.ijmp.jor.br

v. 6, n. 4, October - December 2015

ISSN: 2236-269X

DOI: 10.14807/ijmp.v6i4.361

Foreign companies abound and many of them are new to many markets. It appears a new transnational professional and immigration is common and possible. Transportation and communication become faster and secure helping the interexchange of human, technological and financial capitals.

As there is a continuous reconfiguration of the political space and power, social tensions and inequalities are becoming part of the day-to-day scenario of many cities and nations.

In this context, cultural homogenization is seen as an invasive factor for many people or as a must for others. Additionally, social sciences must change as they refer to the past and seems static to measure a changing social environment. As an example, they do not measure new categories such as transnational professional immigrants or national supply chains.

\subsection{Identity}

A fast and turbulent time is forcing the integration and fragmentation of each individual. There is a travelling identity and people lack universal certainties. History of each population is forgotten, and consequently identity is diluted.

There is a new social segmentation combined with the emergence of cosmopolitan and multiple transnational and diverse cultural identities. Also, true subcultures are appearing which promote the disintegration of many local cultures. In contrast, nationalism is invigorated in many populations.

The metaphor and utopia explain everything, and the individual is taken apart from the center of the scene.

There is a loss of individuality and global context, and every human being is immersed in a transitory world, full of mercantilism and a here-and-now position. As a result, it is not believed in values, virtues and institutions, and identity is linked more with goods that somebody access than with the place that she/he was born.

\subsection{Economic ambience and companies}

The global/international context represents a must for growth, but obliges to operational and competitive considerations.

Beginning the '90s, neoliberalism has entered in the worldwide scene and citizens' power passed to the investor. As a consequence, the old logic collapsed, 


\section{INDEPENDENT JOURNAL OF MANAGEMENT \& PRODUCTION (IJM\&P)}

http://www.ijmp.jor.br

v. 6, n. 4, October - December 2015

ISSN: 2236-269X

DOI: 10.14807/ijmp.v6i4.361

and values and models were given to the hands of the commercial organizations and people. The instrumental rationality took the place of the universal reason.

For organizations and individuals to live close and out of the world is no longer applicable. That is one of the fundamental reasons why transnational firms are being developed beyond the geographical and political boundaries of their home countries.

Concepts like global, glocalization and multiple locations are part of a restless business environment in which small and medium enterprises are emerging.

Imbalances and dispossession have been installed at all levels, and there is an ongoing discussion on the limits of the welfare State and who finances many businesses.

Work is being transformed to a flexible specialization and fragmentation of production processes. Value chain is seen in a holistic manner and value proposition lasts on minor and subtle details.

Internet democratizes information, and everyone can access to uncountable electronic spaces, which are combined with other non-electronic. Businesses and life are virtual and real at the same time, and both are confused.

Organizations need to innovate, communicate and use technology in different ways. From one side, strategy must be conceived for volatile and turbulent times, and marketing turns to global markets which mostly are unknown and unpredictable. On the other hand, processes don't stand for what it is needed in the future, they require rebuilding their overall value proposition. Consequently, there is a huge challenge on management and human resources.

On the management side, the way we do in the organizations is not applicable anymore: many management tools that are used today have more than 80 years, like organizational hierarchies, brand management and time and motion studies. Also, they were in good tune with an economy of goods production of elder times but not with the knowledge economy in which we are immerse today. Specifically, if things should be done differently, a change is needed in the way that the basic management processes, like talent selection, budgeting and planning are being managed. 
INDEPENDENT JOURNAL OF MANAGEMENT \& PRODUCTION (IJM\&P)

http://www.ijmp.jor.br

v. 6, n. 4, October - December 2015

ISSN: 2236-269X

DOI: 10.14807/ijmp.v6i4.361

On the human resources side, learning and training should be thought for times that have not come yet. In this sense, there is a need in recognizing new business drivers and understand future markets and products to set up priorities on skills and competencies that will be needed to be developed.

\subsection{State-nation and power}

States/nations are facing ambiguity, versatility and a new dimensionality in their relations with others (meant as other States/nations, organizations and individuals).

New powers are changing their identity and relationships, and they don't necessarily depend on natural resources, as knowledge is the new value added metric for consumers all over the world.

Executives gain more control and power because is who deals with international organizations and powers like IMF (International Monetary Fund), WTO (World Trade Organization), international financial markets, international courts, or organizations dedicated to the environment and human rights. That's one of the reasons why the democratic quality is affected in most countries. In this situation, States decline and marginalization increases, having specialists which advert that the scope of democracy should be reviewed. Moreover, there are issues as environmental or human rights that exceed the reality of countries and become a transnational problematic.

As a summary, it was said that globalization has turned to a volatile and definite concept at the same time, proposing new dimensions, an apparent cultural homogenization and novel users' categories. Also, new transportation and communication methods and tools, are helping to reach the most unexpected places in fast times.

The whole society and human beings have been crossed by this phenomenon which impacts decision making at collective and individual levels.

Society has a new physiognomy with new actors, categories and conflicts showing new social segmentations, subcultures and nationalisms. Social sciences (and specifically, census and marketing studies) are needed to be rethought. They lost their tune with reality. In addition and in many countries, the institutions got heart and the data and information they produce, too. As a result, decision making 


\section{INDEPENDENT JOURNAL OF MANAGEMENT \& PRODUCTION (IJM\&P)}

http://www.ijmp.jor.br

v. 6, n. 4, October - December 2015

ISSN: 2236-269X

DOI: 10.14807/ijmp.v6i4.361

processes are affecting not only internal structures of organizations but also their partners and context.

The individual identity is diluted, being exposed to fragmentation and integrations at the same time, depending on others' views. The results are superficial, external and perishable patterns. Everything is transitory and connected with material things, disbelieving of values, virtues and institutions. The world becomes unstable and uncertain, and does not belong to a fixed and unchanging place, bringing about cosmopolitism and multiple identities. Identity does not respond to the place where somebody was born, but to a specific moment and to the goods that somebody acquires.

Economically, globalization is connected with internationalization, mobile investments, products and processes standardization, and global supply/value chains. Trade is the king as instrumental rationality took the place of universal reason. Long term becomes short term for many organizations and many investors show impatience to develop new businesses.

Becoming a player in an industrial sector is practically connected to "thinking globally and acting locally" (globalization). The "global village" doesn't admit local players. This is helped by poor labor conditions in many countries, flexible specialization and processes fragmentation. Strategic, marketing, technological and operational efficiencies are extremely required in order to be able to compete. Thus, globality, globalization and multiple localizations are new aspects in the decision making process which leaders must consider.

Besides, foreign direct investments (FDI) are causing inequalities in different countries and regions, and factors like education levels, innovation, resources, flexibility and easy-to-make-business-with are key in the future capital movement, that do not respond to a dominant logic and creates threats everywhere. Consequently, new and unknown champions are hearting many traditional markets.

Finally, globalization affects everybody and it is impossible to live in closed contexts and out of what is going on. New roles and new kind of decisions need to be considered, engendering a rethought on leadership and processes.

The universe is in the outdoor, and regions, States/nations, organizations and people have an "adapt or die" challenge to be pursued. Businesses and the way they 
are conceived are not an exception. Therefore, dominant logic, spaces and times have changed abruptly, and old management and market tools don't reflect this evolution.

\section{INNOVATION KEY DRIVERS}

The business world is changing rapidly, and huge differences in how companies operate are about to come. For Prahalad (2012) new opportunities and a new way to compete will come out from the following five key drivers:

- Globalization.

- Connectivity: For the first time in human history, 3 billion people are connected through cellular phones and this number will increase.

- The costs of digital technologies are going down dramatically: the starting point is the cellular phone that can be acquired for $\$ 30$ as 16 gigabytes of USB memory. This means that technology does not differentiate any longer between the rich and the poor. Everybody can have the same technology.

- Convergence of technologies: a product like a cellular phone is a cell phone, a computer, a camera, a watch. All this technologies are built coming together.

- Social networks are becoming extremely important, too.

The author adds that these five forces will create new wealth and that the question is "how would the poor and the rich markets change and therefore how we would create value".

In addition, Walters (2008) asserts that Prahalad \& Krishnan reminds us that modern business is not only a matter of Web 2.0 and consumer tech but of two main ideas:

- $\mathrm{N}=1$, as a way to say that "value is based on unique, personalized experiences of consumers". So, no matter how many consumers may a firm has the focus should be on individuals.

- $\mathrm{R}=\mathrm{G}$, meaning that resources are global and they are in a "variety of other big and small firms", constituting a global ecosystem. That is, that firm's efforts should be "on gaining access to resources, not necessarily owning them". 
INDEPENDENT JOURNAL OF MANAGEMENT \& PRODUCTION (IJM\&P)

http://www.ijmp.jor.br

v. 6, n. 4, October - December 2015

ISSN: 2236-269X

DOI: 10.14807/ijmp.v6i4.361

To make this happen there are some shifts which are required: from "impersonal to customized offerings, from vertical to horizontal organizations". Firms will have to go against many paradigms and "rethink its fundamentals to success within the $N=1, R=G$ world". UPS is given as an example. This firm transformed the picking-up-packages business process from "requiring customers to drop off parcels at a central collection point to picking up packages from clients at specific times".

Another mentioned example, Madras Cements, is a firm which deployed a sophisticated and expensive GPS technology to truck movements and goods by a $\$ 30$ cell phone communication via SMS that was processed timely to improve driver performance, helping executives on the identification of areas of improvements. Finally, an important auto supplier teaches that, while they shifted sourcing to China, no cost saving was achieved while lost in flexibility and longer lead times indicated a need to rethink the entire process (Walters, 2008).

Subsequently, businesses must be rethought. None of what is being done will probably be done in the future. The $N=1, R=G$ world represents a peril for firms that don't understand that the new era of innovation will take products, services, processes and practices. Strategic and operational flexibility and unprecedented time-to-market are key drivers of this era.

Additionally, it is extremely important to get the big picture and to have less codified processes and systems. In other words, there will be unforeseen consequences that the future will bring about for the ones that miss this opportunity. The business landscape is under transformation independently of what anybody alone would like or want.

\section{COMPETITIVE ADVANTAGE (CA)}

CA can be understood as a general guide when making different plans and taking actions to build a new business, achieving the necessary objectives.

Porter (1991) states that it is needed to understand where the firm stands, know its context and main characteristics. In other words, it is needed to analyze the attractiveness of the industrial sector in which the company competes and to make that analysis suggests the five competitive forces model (rivalry among competitors, bargaining power of vendors and clients, substitute products, and finally, threats of new competitors). Additionally, remarks that establishing a CA is needed to work on 


\section{INDEPENDENT JOURNAL OF MANAGEMENT \& PRODUCTION (IJM\&P)}

http://www.ijmp.jor.br

v. 6, n. 4, October - December 2015

ISSN: 2236-269X

DOI: 10.14807/ijmp.v6i4.361

drivers like economies of scale, costs, product differentiation, capital investments and access to distribution channels.

For other authors like Best (2007) to find a CA implies finding advantages against competitors and it may come up from costs, differentiation and marketing advising that firms should focus on one of these three alternatives. Porter (1991) suggests three generic strategies, coinciding with Best in the first two and proposing as a third one to focus on specific niches.

Finally, Christensen (1998) advises that it is required a constant review on market and business behavior as internal and external changes affect directly firm's offering. In this way, CA can change in accordance to market conditions and new consumers' behavior.

As a result and in the long run, company growth depends on CA and its evolution. Prior business knowledge and market analysis are necessary in order to have a better perspective on business potential.

In the following Figure 1 it is showed a summary of what was proposed in this section:

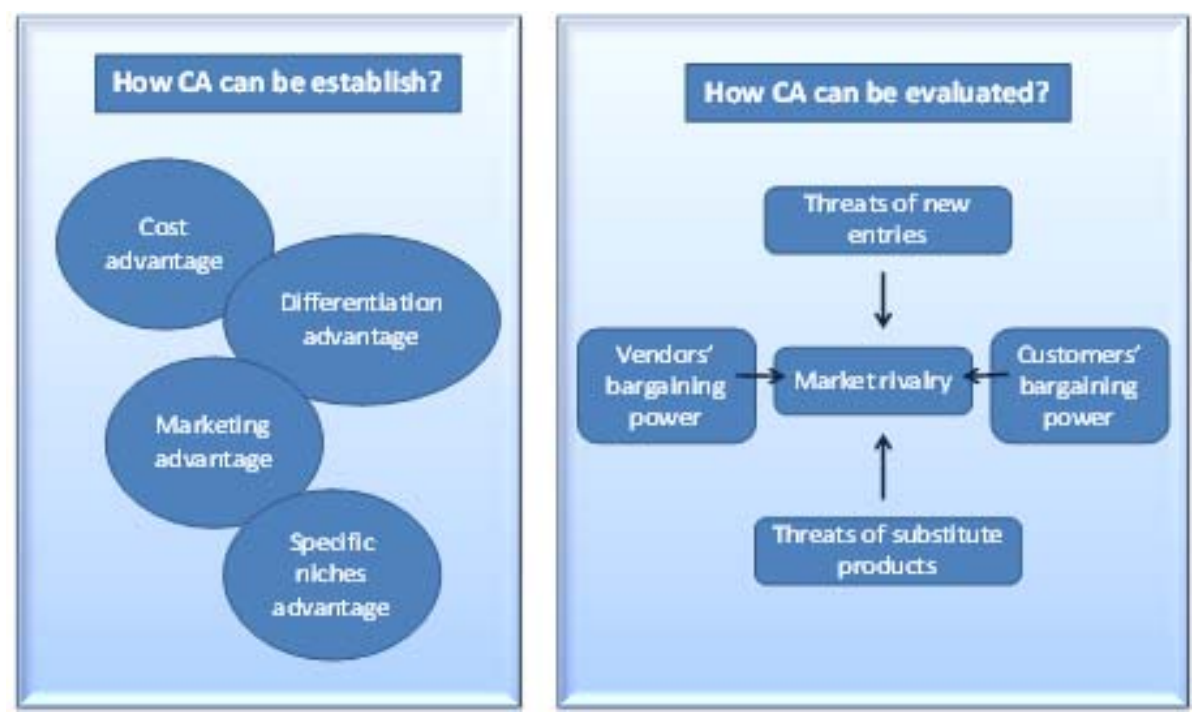

Figure 1: Competitive Advantage (CA)

\section{FUNCTIONAL AND INNOVATIVE PRODUCTS}

Products are found in different places, respond to different needs and therefore, have different characteristics. Key factors like demand, competitors and margins should be considered while analyzing them. As a result, Fischer (1997) distinguishes between functional and innovative products, as follows: 
- Functional products: are found in retail shops and have a predictable demand, as they respond to basic needs which don't change through time. They are connected to incremental innovations and propose low margins. Typical examples of these products are found in the consumer business domain.

- Innovative products: are found in specific places and have an unpredictable demand, as they answer to not basic needs, which change through time. As they are connected with breakthrough innovations, they offer high margins. Generally, technological products may be good examples of innovative products.

The author refers that firms like Obermeyer (a private skiwear firm) launches every year $95 \%$ of their products with new designs. That is why, usually their demand forecasts err by $200 \%$. Therefore, they have little time to react because the season is short. On the contrary, Campbell Soup Company launches $5 \%$ of new products each year and their existing products have been in the market for years. As a result, demand is satisfied immediately with inventories and their market cycle time is around 6 months. Therefore, for innovative products, flexibility and time-to-market are key factors and for functional products, it is required to be focused on operational efficiencies.

The following Table 1 shows a summary of what was said in this paragraph:

Table 1: Functional and Innovative products

\begin{tabular}{|l|c|c|}
\hline & Functional Productions & Innovative Products \\
\hline Where are they found? & Retail (stores an gas stations). & Specific places. \\
\hline What needs they satisfy? & $\begin{array}{c}\text { Basic: don't change through } \\
\text { time and are stable. }\end{array}$ & Not basic: new and not stable. \\
\hline How is the demand? & $\begin{array}{c}\text { Stable and predictable. Stands } \\
\text { for long periods of time. }\end{array}$ & $\begin{array}{c}\text { Variable, volatile and } \\
\text { unpredictable. Stands for short } \\
\text { periods of time. }\end{array}$ \\
\hline What about competitors? & Invite to competition. & Invite to imitators. \\
\hline What margins do they offer? & $\begin{array}{c}\text { Low. That is why they are } \\
\text { related to incremental } \\
\text { innovations. }\end{array}$ & $\begin{array}{c}\text { High. That is why they are } \\
\text { related to breakthroughs. }\end{array}$ \\
\hline Examples (industrial sector) & Consumer products. & Technological products. \\
\hline
\end{tabular}

Summarizing, organizations need to identify their different products and manage them in different business units, each one with specific policies, strategies and operational processes. 


\section{BUSINESS PLANS (BP) versus LEARNING PLANS (LP)}

Startups and new businesses are common in the business world. In addition, technology and new communication tools are game-changing factors for many industrial sectors. In this context, ideas are the raw material to progress and establish a sustainable CA. Christensen (1998) specifically endorses that ideas for new businesses don't come completely delineated. Some of them are undercooked and should follow a process.

Additionally, novel ideas are the basis to build new and innovative products, and in contrast incremental ideas support existing or functional products. Specifically, growth may come from a combination of novel or existing markets and products. Hanlon (2013) says that Ansoff Matrix², which relates products and markets, can be applied to find new opportunities to grow revenues through developing new products/services or tapping into new markets, as per the following four strategies:

- Market penetration strategy: existing products in existing markets.

- Market development strategy: existing products in new markets.

- Product development strategy: new products in existing markets.

- Diversification strategy: new products in new markets.

More than ever, firms need to find new ways to increase revenues out of their traditional boundaries. New markets and new products are a must in an increasingly mature developed world. By contrast, Prahalad (2006) demonstrates that emerging economies propose new paradigms and novel ways to understand products/services and markets and that there is a fortune at the bottom of the pyramid.

Correspondingly, new and existing businesses respond to different settings, as it is shown in the following Table 2:

${ }^{2}$ It is not the objective of this paper to deepen this tool. What it is intended to emphasize is that increasingly there are new products and new markets in most of the industrial sectors. 
INDEPENDENT JOURNAL OF MANAGEMENT \& PRODUCTION (IJM\&P)

http://www.ijmp.jor.br

v. 6, n. 4, October - December 2015

ISSN: 2236-269X

DOI: 10.14807/ijmp.v6i4.361

Table 2: New and existing businesses

\begin{tabular}{|l|c|c|}
\hline & New business (Startup) & Existing business \\
\hline $\begin{array}{l}\text { Do ideas come completely } \\
\text { delineated? }\end{array}$ & No & Yes \\
\hline $\begin{array}{l}\text { What kinds of innovations are } \\
\text { needed? }\end{array}$ & Novel/Breakthrough & Existing \& Functional \\
\hline What products support? & New \& Innovative & Campbell Soup Company \\
\hline Examples & Obermeyer & $\begin{array}{c}\text { Market penetration \& Market } \\
\text { development }\end{array}$ \\
\hline Ansoff related strategy & Diversification & Developed \\
\hline Related type of economy & Emerging & No \\
\hline $\begin{array}{l}\text { Are needed new ways to } \\
\text { interpret markets, products and } \\
\text { services? }\end{array}$ & Yes & \begin{tabular}{c} 
Product \\
\hline
\end{tabular}
\end{tabular}

As a consequence, new products/services and original ways to interpret markets are increasingly required. However, Christensen et al. (2008) say that the stage-gate system used in incremental innovations is sabotaging innovation in the following main areas:

- Funding: To win it is a nanoseconds exercise, twitting assumptions and running another full scenario to have a better net present value of the same project.

- Strategy: assuming that the strategy for disruptive innovations has a right strategy as the stage-gate system assumes in incremental innovations, which have a known strategy and a skillful execution. By contrary, disruptive innovations have an unknown strategy and a variable execution.

Authors insist that as it was shown "the stage-gate system is not suited for the task of assessing innovations whose purpose is to build new growth business". As a result, discovery-driven planning (or Learning Plans, LP) should be used to reverse some steps for which the stage-gate process is not capable. The following considerations are offered for LPs:

- It should be established a minimum accepted revenue, income statement and cash flow. We add that data, analysis and full back ups are required in BP.

- As it is not a plan to execute (like BP) but to learn (LP), assumptions' checklist should be built, which must prove true to materialize these numbers. A set of plausible assumptions must support the case for success, if not the project should be killed. 
- LPs offer a way to illuminate management and "assumptions constitute the key uncertainties". As a result, a go-to market and test the assumptions as many times as it is required, and come back to the design table.

- LPs should be routed to asking important questions, rather than arriving to apparently correct answers.

- LP "is more used in entrepreneurial settings than in large corporations that desperately need them".

They conclude that:

- There are no good tools to help managers "understand markets, build brands, find customers, select employees, organize teams and develop strategy".

- Some financial analysis and decision making tools about investments "distort the value, importance and the likelihood of success of investments in innovation".

- Managers must challenge paradigms and develop alternative methodologies.

As a result, LPs are applicable to new products/services and/or markets as variables are unknown and BPs to existing products/services and/or markets as variables are more predictable. In addtion, LPs require to be assigned a specific amount of money that will serve to learn about the new venture in the market. That is why the key questions on LPs are: what have we learned? and if the new knowledge that was got is applicable for this specific project or another in the future?

The following Table 3 shows the fundamental concepts that were shown on BPs and LPs in this section: 
INDEPENDENT JOURNAL OF MANAGEMENT \& PRODUCTION (IJM\&P)

http://www.ijmp.jor.br

v. 6, n. 4, October - December 2015

ISSN: 2236-269X

DOI: 10.14807/ijmp.v6i4.361

Table 3: Business plans versus Learning plans

\begin{tabular}{|c|c|c|}
\hline & Business Plan (BP) & Learning Plan (LP) \\
\hline Objective & Execution & Learning \\
\hline Strategy & Known & Unknown \\
\hline Execution & Skillful & Variable \\
\hline Process & Stage-gate-system & $\begin{array}{l}\text { Market Check and continuos } \\
\text { come back to the design table }\end{array}$ \\
\hline What is needed? & $\begin{array}{c}\text { Data, analysis and full back } \\
\text { ups. }\end{array}$ & $\begin{array}{c}\text { Minimum accepted revenue, } \\
\text { income statement and cash } \\
\text { flow. }\end{array}$ \\
\hline Assumptions & $\begin{array}{l}\text { Known. Constitute key } \\
\text { certainties }\end{array}$ & $\begin{array}{l}\text { A set of plausible assumptions } \\
\text { must support the case. } \\
\text { Constitute key uncertainties. }\end{array}$ \\
\hline Routed to & Finding correct answers. & Asking important questions. \\
\hline Sabotage innovation? & On funding and strategy & \\
\hline $\begin{array}{l}\text { Traditional financial } \\
\text { analysis/decision making tools. }\end{array}$ & Applicable & $\begin{array}{l}\text { Value distortion on investments } \\
\text { in innovation }\end{array}$ \\
\hline Management attitude & Business as usual & $\begin{array}{l}\text { Challenge paradigms and } \\
\text { develop alternative } \\
\text { methodologies. }\end{array}$ \\
\hline Applicable to & $\begin{array}{l}\text { Existing products/services } \\
\text { and/or markets }\end{array}$ & $\begin{array}{l}\text { New products/services and/or } \\
\text { markets. }\end{array}$ \\
\hline
\end{tabular}

\section{CONCLUSIONS}

The world is profoundly under constant change. Different forces have been shaping a new framework in which volatility and the unknown are opening new avenues to a future in which innovation seems the only possibility for survival. CA has become a construct for shorter periods of time; flexibility and adaptability are a must at this time.

Globalization proposes a new dimensional interrelationship of all that is known, with an apparent cultural homogenization and novel user's categories that are not included in current analysis. As a consequence, social sciences must be rethought as they have lost tune with reality. Addtionally, affects decision making at collective and individual levels, and also the internal and external organizational structures. The individual identity is subject to other's opinion, multiple identities and to perishable patterns. Identity is connected with the goods that somebody acquires.

In economic terms, globalization is referred to internationalization, mobile investments, standardization of products and processes, and global supply/value chains. Organizations need to foster their ability to "think globally and act locally" inside their internal and external structures. Therefore, flexibility, specialization and processes fragmentation are the new ways to dislocate work among the internal structures of the organizations. Under this paradigm managers are inmerse in a decision making process with globality, glocalization and multiple locations. 


\section{INDEPENDENT JOURNAL OF MANAGEMENT \& PRODUCTION (IJM\&P)}

http://www.ijmp.jor.br

v. 6, n. 4, October - December 2015

ISSN: 2236-269X

DOI: 10.14807/ijmp.v6i4.361

Everything is "just now and far away". In addtion, FDI moves quickly causing inequalities everywhere generating that new champions abound in many traditional markets.

Thanks to globalization it is not possible to live in closed contexts and new roles and decisions should be taken. As a consequence, leadership and the way we do should be rethought, including the old management tools that we still use. The challenge is to "adapt or die" not only for business people but to everybody. Dominant logic, spaces and times have changed abruptly.

Under the $\mathrm{N}=1 \mathrm{R}=\mathrm{G}$ paradigm, products, services, processes and practices need to be rethought. Generally, the comon mistake in start-ups is that are used techniques that come from existing businesses which require skillful execution. That is rigid and detailed stage-gate-systems related to incremental products with known assumptions. Consequently, traditional financial analysis and decision making tools are only applicable to existing products and markets, which turn completely new everyday. Focus should be on asking the correct questions, not finding the correct answers.

Thus, under globalization borderless geography, innovation and competitive advantages uncertainties, and the distinction that should be made between functional and innovative products, LPs represent an excellent reply to these problematics as they propose to continuosly check a set of assumptions in the market going back to the design table, as many times as it is needed, not using traditional standard investments and decision making tools "as-they-are". In other words, LPs portray a flexible work plan and a learning process for fast-changing times.

Finally, executives and managers should challenge old paradigms and develop alternative methodologies in order to enhance the odds of success of their new projects. More than ever LPs should be used as their applicability is on changing volatile cirmcunstances in which variables are unknown. As the unpredictable is part of our comon lives today and business as usual is rare BPs are about to die. 


\section{REFERENCES}

CHRISTENSEN, C.; KAUFMAN, S. P.; SHIH, W. (2008) Innovation killers, How financial tools destroy your capacity to do new things, Harvard Business Review, USA: Boston.

CHRISTENSEN, C. (1998) The innovator's dilemma: When technology cause great firms to fail, Harvard Business Review Press, USA: Boston.

FISCHER, M. L. (1997) What is the right supply chain for your product, Harvard Business Review, USA: Boston.

HAMEL, G.; BREEN, B. (2007) The future of Management, Harvard Business School Press, USA: Boston.

HANLON, A. (2013) Essential Marketing Models: Classic planning tools to inform strategy, from http://www.smartinsights.com/marketing-planning/create-a-marketingplan/ansoff-model/, recovered 08/07/2015.

PORTER, M. (1991) Strategy: Seeking and securing competitive advantage, Harvard Business Review, USA: Boston.

PRAHALAD, C. K. (2006) The fortune at the bottom of the pyramid: Eradicating poverty through profits, Pearson Education Inc/Wharton School Publishing, USA: NJ.

PRAHALAD, C. K.; KRISHNAN, M. S. (2008) The new age of innovation: Driving co-created value through global networks, McGraw Hill, India, Pvt Limited.

PRAHALAD, C. K. (03/08/2012) C. K. Prahalad: Innovation's Newest Age, from:

https://www.youtube.com/watch?v=Jf6HoLMhJR0, recovered: 08/08/2015.

STUTELY, R. (2012) The definitive Business Plan, Pearson Education Limited, UK: Harlow.

VILTARD, L. A (2015) Innovación organizacional: su comprensión, puesta en marcha como proceso y medición (Organizational innovation: its Understanding, implementation as a Process and measurement). B. S. Lab, Italy: Avellino.

VILTARD, L. A. (2013) Globalización: Entender el nuevo ámbito mundial y tomar decisiones (Globalization: Understanding the new worldwide context and take decisions), B.S. Lab, Italy: Avellino.

WALTERS, H. (May, 19, 2008) C. K. Prahalad: The new age of innovation, from: http://www.bloomberg.com/bw/stories/2008-05-19/c-dot-k-dot-prahalad-the-new-ageof-innovationbusinessweek-business-news-stock-market-and-financial-advice, recovered: 08/08/2015. 